\title{
Protocol Deviation End Date Time
}

National Cancer Institute

\section{Source}

National Cancer Institute. Protocol Deviation End Date Time. NCI Thesaurus. Code C87992.

The date and time a protocol deviation has concluded. 